\title{
cyp11A1 CANOLA PLANTS UNDER SHORT TIME HEAT STRESS CONDITIONS
}

\author{
L.O. SAKHNO ${ }^{1}$, M.S. SLYVTS ${ }^{1,2}{ }^{2}$, M.V. KUCHUK ${ }^{1}$ \\ ${ }^{1}$ Institute of Cell Biology and Genetic Engineering NAS of Ukraine, Kyiv \\ E-mail: sakhno@icbge.org.ua \\ ${ }^{2}$ National Technical University of Ukraine «Kyiv Polytechnic Institute»
}

In order to investigate the high temperature tolerance of spring canola plants (Brassica napus L.) constitutively expressing cyp 11A1 gene which encodes bovine cytochrome $P 450_{S C C}$ the growth features were analyzed under short time heat stress $\left(42^{\circ} \mathrm{C}\right)$ in growth chamber. Earlier it was documented that results of the heat tolerance test positively correlated with improvement of high temperature resistance in field trial. Higher relative water content (by $13 \%$ ) and superoxide dismutase (SOD) activity, lower electrolyte leakage (up 1.4-fold) and smaller increase in chlorophyll a and carotenoid contents in cyp 11A1 canola leaves in comparison with wild-type plants under stress allowed to conclude cyp 11 1A1 plants are more tolerant to high temperature than the control ones. We suppose that SOD activity increase which revealed in our transgenic canola in normal condition plays the defining role in the biochemical alterations in plant metabolism for the thermotolerance improvement. SOD activity increment could be caused by heterologous cytochrome $P 450_{S C C}$ activity which resulted in the superoxide radical formation. Cyp11A1 canola plants might be resistant to the other stress conditions of different origin.

Key words: Brassica napus, cyp 11A1, cytochrome P450 ${ }_{S C C}$, photosynthetic pigments, heat stress, SOD.

Introduction. Increasing the oil content, quality and yield remains the major aim of oilseed rape (Brassica napus L.) breeding. Resistance to abiotic stresses becomes essential characteristic of plants because of climate changes.

Biotechnological methods are successfully used for understanding plant abiotic stress tolerance [1] and for applying for rapeseed creation with different stress resistance [2-5]. Transgenic canola plants overexpressing a vacuolar $\mathrm{Na}^{+} / \mathrm{H}^{+}$antiport from Arabidopsis thaliana were able to grow, to flower, and to produce seeds in the presence of $200 \mathrm{mM} \mathrm{NaCl}$. Seed yields and seed quality were not affected by the high salt concentration [2]. Overexpression of wheat mitochondrial $\mathrm{Mn}$ superoxide dismutase (Mn SOD3.1) enhanced transgenic canola heat, drought and cold tole-

(C) L.O. SAKHNO, M.S. SLYVETS, M.V. KUCHUK, 2014 rance both in the field and under artificial stress conditions [3]. Transgenic B. napus carrying bsubunit of Arabidopsis farnesyltransferase (ERA1) antisense construct driven by a drought-inducible rd29A promoter were more resistant to seed abortion induced by water deficit during flowering [4]. Field trials suggested that with adequate water, transgenic canola produced the same amount of seed as the parental control. Under moderate drought stress conditions at flowering, the seed yield of transgenic plants was significantly higher than the control [4]. Overexpression of the RNAbinding domain of the flowering control locus $\mathrm{A}$ protein led to increase in plant size, organ size, cell size, plant productivity, and oil content in transgenic rape plants by down-regulating the cell-cycle-related cyclin-B2-1 gene, an activator of cyclin-dependent kinase 1 [5]. Transgenic tall fescue (Lolium arundinaceum Darbyshire) plants expressing CuZnSOD and ascorbate peroxidase genes in chloroplasts under the control of the oxidative stress-inducible promoter, sweet potato peroxidase anionic 2 (SWPA2), have improved resistance to several abiotic stresses, such as methyl viologen, $\mathrm{H}_{2} \mathrm{O}_{2}$, and the heavy metals (copper, cadmium, and arsenic) [6].

We have constructed canola lines carrying bovine cyp 11A1 gene in their nuclear genome [7] using Agrobacterium tumefaciens-mediated leaf disk transformation [8]. This gene encodes cytochrome $\mathrm{P} 450_{\text {SCC }}$ from bovine adrenal cortex mitochondria and was shown to affect the biosynthesis of steroid compounds in transgenic tobacco (Nicotiana tabacum L.) [9]. Obtained canola plants were resistant to BASTA herbicide treatment in greenhouse conditions due to bar gene expression. It was used in transformation cassette as a selective marker. Some of transformants accumulated an increased amount of total soluble proteins in leaves and seeds. They have enhanced antioxidant activity in leaf tissues. Some of them flowered 5-7 days ear- 
lier than the control plants. Changes in fatty acid composition of leaf lipids were detected by using gas chromatography [10]. We have shown that the integration of cyp $11 \mathrm{~A} 1$ gene of animal origin under constitutive (35S) promoter also affected canola oil composition. Increase in oleic acid (from 66 to 73 mole\%) was accompanied by decrease in linolenic (from 6 to 3 mole\%) acid. The total fatty acid content in canola seeds remained at the level of control plants. Superoxide dismutase (SOD) activity in transgenic cyp11A1 canola leaves was higher than in the control ones on $\sim 30 \%$ in optimal aseptic conditions. Plant testing for in vitro osmotic stress resistance made it possible to identify the line that could generate biomass under hyperstress comparable with the control one in the normal conditions [11]. Analysis of seed germination under high temperature revealed differences between control and cyp $11 \mathrm{~A} 1$ seedlings in fresh weight, hypocotyl and root length, SOD activity [12].

A number of changes mentioned for cyp $11 \mathrm{~A} 1$ canola plants are inherent in the plants with heterologous SOD expression, which are characterized by increasing adaptive properties when they were subjected to stresses of various origins $[3,13]$. And the aim of the present work was the investigation of cyp 11A1 canola thermotolerance by using the short time heat stress. It was documented that results of the heat tolerance test (short-time growth under $42{ }^{\circ} \mathrm{C}$ in growth chamber) positively correlated with improvement of high temperature resistance in field trial [3]. We analyzed such physiological and biochemical parameters which are usually used to characterize the properties of plants under stress as relative water content $[14,15]$, electrolyte leakage $[15,16]$, photosynthetic pigment content and ratios [15, 17-19], SOD activity [3, 20, 21].

Materials and methods. Spring canola plants (Brassica napus L.) cv Mariia (National Agrarian University of the Ukrainian Academy of Agrarian Sciences selection) were used as the control plants because earlier they were used for primary cyp 11A1 transformant creation [7]. Transgenic homozygous $\mathrm{T}_{2} 1 \mathrm{a}$ and $\mathrm{T}_{2} 2 \mathrm{c}$ lines which were obtained by self-pollination of primary transformants under greenhouse conditions [7] ( $T_{2}$ generation) were also analysed. They were selected as the most tolerant to osmotic stress in previous experiments under in vitro conditions [11]. Aseptic plants were transplanted into soil in greenhouse (12/12 photoperiod,
$+23{ }^{\circ} \mathrm{C}$ ). After two weeks they were transferred into Programmable Plant Growth Chamber, model WGC-P9 (WiseCube ${ }^{\circledR}$ WGC, Korea).

Heat tolerance tests were conducted after two week chamber growth under the following conditions: $16 \mathrm{~h}$ (light) $/ 8 \mathrm{~h}$ (dark) photoperiod, temperature $+22{ }^{\circ} \mathrm{C}$ (day) $/+18^{\circ} \mathrm{C}$ (night), $70 \%$ humidity, $480-550 \mu \mathrm{mol} / \mathrm{m}^{2} \mathrm{~s}$ light intensity). Humidity and light intensity were taken without changes. Temperature was increased with $2{ }^{\circ} \mathrm{C} / \mathrm{h}$ gradient to $42{ }^{\circ} \mathrm{C}$. Plants were than taken isothermal at $42{ }^{\circ} \mathrm{C}$ for $16 \mathrm{~h} \mathrm{[3].}$

SOD activity was measured by using photochemical oxidation of nitro blue tetrazolium method [22]. Fresh plant material $(100 \mathrm{mg})$ in Eppendorf tube $(1.5 \mathrm{ml})$ was rubbed with $1 \mathrm{ml}$ of $50 \mathrm{mM}$ Tris- $\mathrm{HCl}$ buffer $(\mathrm{pH} 8.0)$ and was centrifuged at $13000 \mathrm{~g}\left(4^{\circ} \mathrm{C}\right)$ for $15 \mathrm{~min}$. The supernatant was used for analyses. Reaction was held in Eppendorf tube $(1.5 \mathrm{ml})$. One tube for each probe was retained in the dark. The others were illuminated with white light lamp (fluorescent lamp T5/G5, model ELI-230A-T5-8W) during $5 \mathrm{~min}$ in thermostat at $23{ }^{\circ} \mathrm{C}$. The optical density of illuminated probe solution was measured at $550 \mathrm{~nm}$ (BioPhotomether Eppendorf, Germany) versus optical density of dark probe. Null probe had no leaf extract in its composition. SOD activity was expressed in relative unit/mg protein.

The total soluble protein content was measured using Bradford method [23].

Relative water content $(R W C$ ) was calculated as

$$
\text { RWC, \% }=100 *(\mathrm{FW}-\mathrm{DW}) /(\mathrm{TW}-\mathrm{DW}) \text {, }
$$

FW - fresh weight of leaf discs $(2 \mathrm{~cm}$ diameter) immediately after sampling; TW - turgor weight the same discs after saturation during $24 \mathrm{~h}$ in Petri dish with deionized water; DW - dry weight the same discs after lyophilisation.

Membrane permeability was estimated by recording electrolyte leakage (EL) [24]. Fresh leaf discs (diameter $2 \mathrm{~cm}$ ) were washed thrice with deionized water to remove adhered electrolytes. Then the samples were placed in the closed vials containing $20 \mathrm{ml}$ deionized water. They were incubated at $25{ }^{\circ} \mathrm{C}$ on rotary shaker for $24 \mathrm{~h}$. Electrical conductivity of the solutions $\left(L_{1}\right)$ were subsequently determined on electroconductometer CyberScan pC510 (Eutech Instruments, Germany). Then the samples were autoclaved at $120{ }^{\circ} \mathrm{C}$ during $20 \mathrm{~min}$ 
and the final electrical conductivity $\left(L_{2}\right)$ was obtained after equilibration at $25{ }^{\circ} \mathrm{C}$. The EL was defined as follows

$$
\operatorname{EL}(\%)=\left(L_{1} / L_{2}\right) \cdot 100
$$

Photosynthetic pigment determination was conducted according Wellburn [25] with dimethyl sulfoxide as a solvent (Dimethyl sulfoxide extra pure, «Merck»). Leaf sample $(50 \mathrm{mg})$ was placed in a vial with $4 \mathrm{ml}$ of the reagent and incubated in a water bath at $67{ }^{\circ} \mathbf{C}$ during $4 \mathrm{~h}$. The extract absorbance was measured at 665,649 , and $480 \mathrm{~nm}$ on spectrofluorimeter «Phluorat-02-Panorama» (Lumex-Marketing, Russia). The calculation was carried out by the formulas:

$$
\begin{gathered}
C_{a}=12.19 \mathrm{~A}_{665}-3.45 \mathrm{~A}_{649}, \\
C_{b}=21.99 \mathrm{~A}_{649}-5.32 \mathrm{~A}_{665}, \\
C_{x+c}=\left(1000 \mathrm{~A}_{480}-2.14 C_{a}-70.16 C_{b}\right) / 220,
\end{gathered}
$$

$C_{a}, C_{b}, C_{x+c}$ - content of chlorophyll $a$, chlorophyll $b$, and total carotenoids, respectively.

Statistical analysis was performed according to Duncan multiple range test. Differences from control values were significant at $p \leq 0.05$. Three independent experiments were conducted in five replications. There were three replications for formazan measurement for each extract.

Results and discussion. High-temperature stress is defined as the rise in temperature beyond a critical threshold for a period of time sufficient to cause an irreversible damage to plant growth and development [26]. High leaf temperatures reduce plant growth and limit crop yields.

Earlier we documented that SOD activity in transgenic cyp $11 \mathrm{~A} 1$ canola leaves was higher than in the control ones in the optimal aseptic conditions [7, 27]. In growth chamber it was up 1.76-fold higher comparable with control at $22{ }^{\circ} \mathrm{C}$ (Fig. 1). Cytochrome $\mathrm{P} 450_{\text {SCC }}$ catalyzes three steps cholesterol oxidation with formation of pregnenolone in animals [28]. Superoxide radicals are formed during these reactions. SOD activity in cyp $11 \mathrm{~A} 1$ canola can be increased due to cytochrome $\mathrm{P} 450_{\mathrm{SCC}}$ activity. It did not change under short time heat stress in cyp $11 \mathrm{~A} 1$ leaves (Fig. 1). SOD activity increased in control by $18 \%$ but it retained lower in comparison with in transgenic ones.

In our experiments of in vitro cyp11A1 growth under osmotic stress we demonstrated that SOD

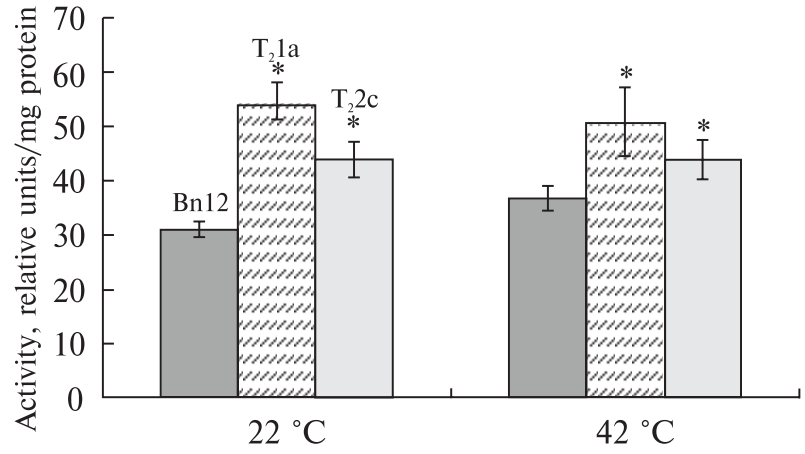

Fig. 1. SOD activity in canola leaves before (growth temperature $22{ }^{\circ} \mathrm{C}$ ) and after (temperature $42{ }^{\circ} \mathrm{C}$ ) heat stress: Bn12 are control plants (cv Mariia), $\mathrm{T}_{2} 1 \mathrm{a}$ and $\mathrm{T}_{2} 2 \mathrm{c}$ are homozygous cyp11A1 lines of second generation. Here and in Fig. 2, 3 error bars represent mean \pm \pm one standard deviation and asterics * indicates significant differences between experimental values compared with the control ones $(p \leq 0.05)$

activity of $\mathrm{T}_{2} 1 \mathrm{a}$ line was higher than the control one in the absence of stress and was unchanged at $100 \mathrm{mM}$ mannitol addition to the culture medium [11]. After mannitol increasing in the medium up to $200 \mathrm{mM}$ SOD activity began to rise markedly in $\mathrm{T}_{2} 1 \mathrm{a}$ line and was maximal in control. It continued to rise at $500 \mathrm{mM}$ mannitol in $\mathrm{T}_{2} 1 \mathrm{a}$, while it decreased in control. SOD activity of cyp $11 \mathrm{~A} 1$ plants increase in normal conditions allows them not to take deteriorating conditions as stress and maintains for prolonged period the unchanged physiological and biochemical characteristics.

It was shown that the innate threshold temperature was dependent upon endogenous SOD and glutathione reductase activity in Gossypium hirsutum plants [20]. Under identical growth conditions, thermotolerant $G$. hirsutum plants had significantly higher optimal and threshold temperatures for the actual quantum yield response of photosystem II and glutathione reductase activity than thermosensitive ones. The authors concluded that maintaining a sufficient antioxidant enzyme pool prior to heat stress is the mechanism for coping with rapid leaf temperature increases that commonly occur under field conditions. Heat stress also increased SOD activity in wild type Nicotiana tabacum plants but this increase was much greater in transgenic plants expressing betaine aldehyde dehydrogenase [29]. The increased thermotolerance induced by accumulation of glycinebetaine was associated with the enhancement of the repair of PSII from heat- 

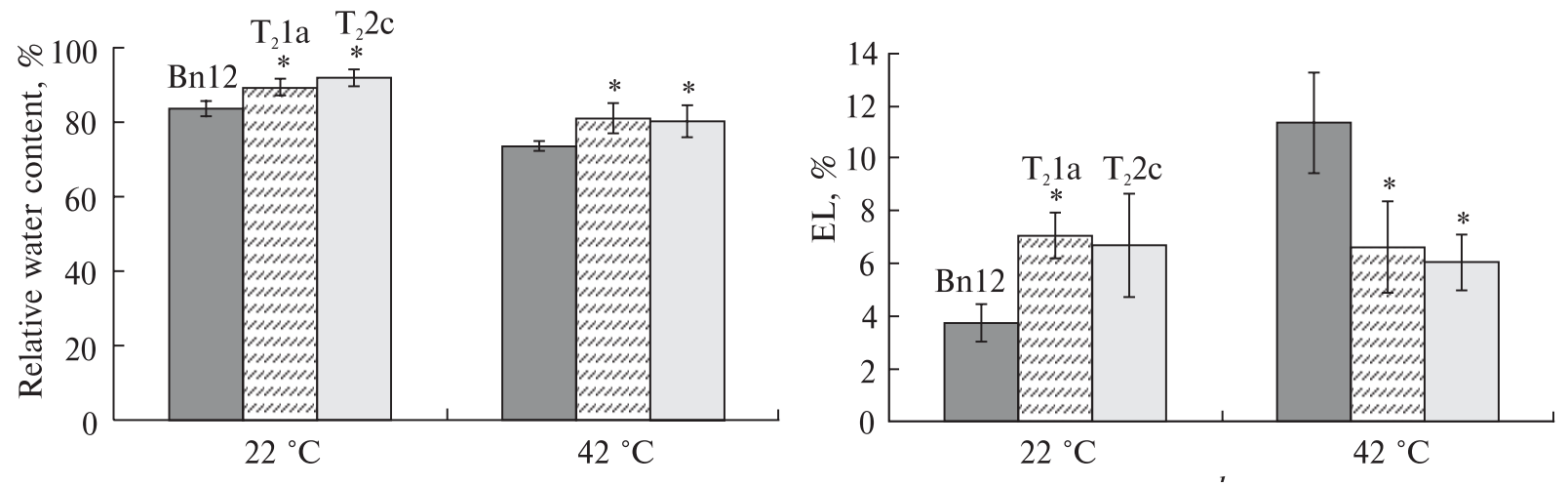

Fig. 2. Relative water content $(a)$ and electrolyte leakage $(b)$ in canola leaves before $\left(22^{\circ} \mathrm{C}\right)$ and after $\left(42{ }^{\circ} \mathrm{C}\right)$ short time heat stress: Bn12 are control plants (cv Mariia), $\mathrm{T}_{2} 1 \mathrm{a}$ and $\mathrm{T}_{2} 2 \mathrm{c}$ are homozygous cyp $11 \mathrm{~A} 1$ lines of second generation

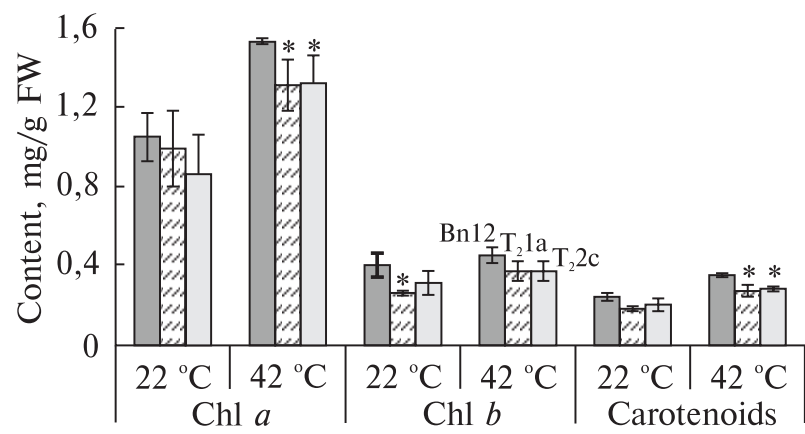

Fig. 3. Photosynthetic pigment content in canola leaves before (growth temperature $22^{\circ} \mathrm{C}$ ) and after (temperature $42{ }^{\circ} \mathrm{C}$ ) heat stress: Bn12 are control plants (cv Mariia), $\mathrm{T}_{2} 1 \mathrm{a}$ and $\mathrm{T}_{2} 2 \mathrm{c}$ are homozygous cyp11A1 lines of second generation

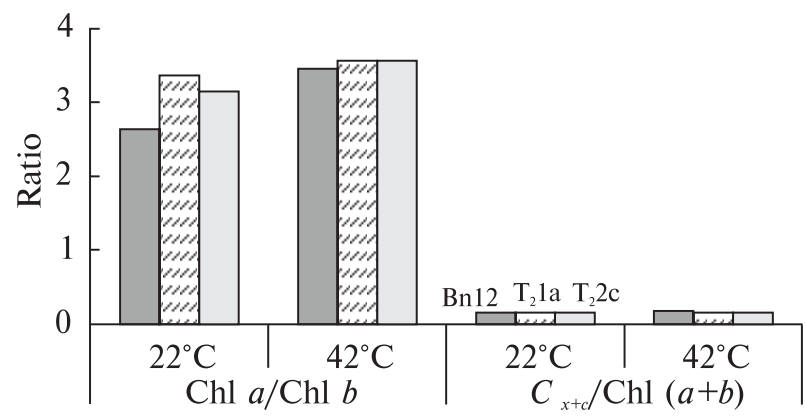

Fig. 4. Photosynthetic pigment ratios in canola leaves before (growth temperature $22^{\circ} \mathrm{C}$ ) and after (temperature $42{ }^{\circ} \mathrm{C}$ ) heat stress: Bn12 are control plants (cv Mariia), $\mathrm{T}_{2} 1 \mathrm{a}$ and $\mathrm{T}_{2} 2 \mathrm{c}$ are homozygous cyp $11 \mathrm{~A} 1$ lines of second generation

enhanced photoinhibition, which might be due to less accumulation of reactive oxygen species in transgenic plants.

We found that the temperature increase led to RWC reduction in all plant tested on 10-13\% (Fig. 2,a). Nevertheless transgenic plants had significantly higher RWC under high-temperature stress. RWC also decreased with prolonged drought, heat, and combined stresses for tall fescue and Kentucky bluegrass (Poa pratensis L.) but the severity of decline varied with stress type and duration [30].

Membrane permeability is an early change indicator of plant physiological functions. It can be used as a criterion of plant tissue resistance to stressors [31]. Conductance-measuring method is one of the most effective and fast way to evaluate degree of cell membrane damage. Analysis of electrolyte leakage from leaf canola tissues revealed differences between the control and transgenic lines (Fig. 2, b). Transgenic plants were characterized by $\sim 40 \%$ increased electrolyte leakage under $22{ }^{\circ} \mathrm{C}$ in comparison with control ones. This may indicate that this temperature was not optimal for cyp $11 \mathrm{~A} 1$ canola. Electrolyte leakage increased significantly (up 2.5 fold) in control plants under heat stress. But it retained without changes in transgenic lines (Fig. 2, b). It testifies the transgenic canola tolerance to short time high temperature. Increased resistance to heat stress was also shown in transgenic canola plants which overexpressed wheat mitochondrial Mn SOD [3]. Electrolyte leakage in most of these plants was lower than in control under high temperature at different growth phases. In chickpea (Cicer arietinum L.) a heat stress investigation has shown that membrane stability significantly correlated $(\mathrm{R} 2=0.7)$ with photosynthetic quantum yield and proved to be viable screening technique 
for thermotolerance [32]. Rice plants expressing MnSOD from pea (Pisum sativum L.) under the control of an oxidative stress-inducible SWPA2 promoter in chloroplasts demonstrated reduced electrolyte leakage compared to wild type leaf slices and exhibited less injury, measured by net photosynthetic rate, under drought stress induced by polyethylene glycol 6000 [33].

Chl a content did not differ in the control and transgenic plants under normal temperature (Fig. 3). It increased at short time heat significantly both in the wild-type and cyp $11 \mathrm{~A} 1$ canola, but this increase was greater in control plants. Chl $b$ content was significantly lower in $\mathrm{T}_{2} 1 \mathrm{a}$ line in comparison with the control and $\mathrm{T}_{2} 2 \mathrm{c}$ plants at $22{ }^{\circ} \mathrm{C}$ growth $(0.26 \pm 0.01,0.4 \pm 0.06$ and $0.31 \pm 0.05 \mathrm{mg} / \mathrm{g}$ fresh weight, respectively). Under heat it did not change in control and $\mathrm{T}_{2} 2 \mathrm{c}$ plants and increased in $T_{2}$ 1a plants at control level. Carotenoid content was higher in control leaves $(0.24 \pm 0.02 \mathrm{mg} / \mathrm{g}$ fresh weight $)$ versus transgenic plants $(0.18 \pm 0.01$ and $0.2 \pm 0.03$ for $\mathrm{T}_{2} 1 \mathrm{a}$ and $\mathrm{T}_{2} 2 \mathrm{c}$ plants, respectively) at initial conditions. After $42{ }^{\circ} \mathrm{C}$ it increased significantly in all canola but this increase was greater in control plants.

Chl $a /$ Chl $b$ ratio was lower in the control plants (2.63) under $22{ }^{\circ} \mathrm{C}$ (Fig. 4) in comparison with transgenic (3.36 and 3.14 for $\mathrm{T}_{2} 1 \mathrm{a}$ and $\mathrm{T}_{2} 2 \mathrm{c}$ plants). Heat affected the increase in it for all plants up 3.45-3.57. Carotenoids/ Chl $(a+b)$ ratio was unchanged both at 22 and $42{ }^{\circ} \mathrm{C}$ for the control as well as cyp11A1 canola (Fig. 4). The study of interrelation between chlorophyll content and heat and/or high photon flux density has shown that the very low chlorophyll content in Syrian barley landrace decreases leaf absorbance which, in turn, reduces the potentially damaging heating effect of high solar radiation in droughted plants [17]. Chl $b$ content retained without changes except for the increase in transgenic $\mathrm{T}_{2} 1 \mathrm{a}$ line at the control level under heat. Carotenoids/ $\mathrm{Chl}(a+b)$ ratio was unchanged both at 22 and $42{ }^{\circ} \mathrm{C}$ for the control as well as cyp $11 \mathrm{~A} 1$ canola. Both chlorophylls and carotenoids also accumulated during acclimation to heat $\left(39^{\circ} \mathrm{C}\right)$ in barley cv Plaisant, leading to an almost constant carotenoid:chlorophyll ratio [17]. Since it was found that membrane stability significantly correlated $(\mathrm{R} 2=0.7)$ with photosynthetic quantum yield under heat [32], we can assume the im- provement of photosynthesis in cyp11A1 canola in comparison with wild type plants because electrolyte leakage was greater in the latter.

Thus, cyp 11A1 constitutive expression proved the higher relative water content in the leaves of transgenic plants in comparison with the control ones under heat stress in growth chamber. Superoxide dismutase activity in transgenic leaves was up $76 \%$ higher comparable with control at $22{ }^{\circ} \mathrm{C}$ and remained unchanged under heat. Electrolyte leakage was lowered. Chl $a$ and carotenoid contents were increased under stress in the control as well as cyp 11A1 canola, but they were lower in the latter. Chl $b$ content retained without changes except for the increase in transgenic $\mathrm{T}_{2} 1 \mathrm{a}$ line at the control level. So it is possible to conclude that cyp $11 \mathrm{~A} 1$ plants can be more tolerant to high temperatures than control ones. We suppose that SOD activity increase which revealed in our transgenic canola plays the defining role in the biochemical alteration in plant metabolism allowing heat stress resistance improvement. SOD activity increase could be caused by cytochrome $\mathrm{P} 450_{\mathrm{SCC}}$ activity which resulted in the superoxide radical formation. Manifestation of bovine cyp 11A1 expression in transgenic canola is the same as heterologous sod overexpression. Plants expressing cyp $11 \mathrm{~A} 1$ gene might be resistant to the other stress conditions both of abiotic and biotic origin.

\section{РАСТЕНИЯ РАПСА С ТРАНСГЕНОМ $c y p 11 \mathrm{~A} 1$ В УСЛОВИЯХ КРАТКОВРЕМЕННОГО ВЫСОКОТЕМПЕРАТУРНОГО СТРЕССА}

\section{Л.А. Сахно, М.С. Сливеи, Н.В. Кучук}

Для исследования устойчивости трансгенных растений ярового рапса (Brassica napus L.), конститутивно экспрессирующих ген cyp11A1, который кодирует

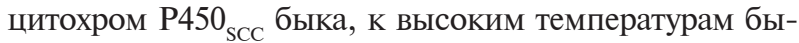
ли проанализированы особенности роста в условиях кратковременного высокотемпературного стресса $\left(42{ }^{\circ} \mathrm{C}\right)$ в климакамере. Результаты этого теста положительно коррелируют с повышением толерантности к действию высоких температур в полевых испытаниях. Увеличение относительного содержания воды (на $13 \%$ ) и активности супероксиддисмутазы (СОД), пониженный выход электролитов (в 1,4 раза) и меньшее повышение содержания хлорофилла $a$ и каротиноидов в листьях трансгенных растений по сравнению с растениями дикого типа в условиях высокотемпературного стресса позволяют сделать вывод о том, что термоустойчивость сур $11 \mathrm{~A} 1$ pac- 
тений рапса выше, чем контрольных. Увеличение активности СОД, обнаруженное в наших трансгенных растениях рапса в нормальных условиях, играет предположительно определяющую роль в биохимических изменениях растительного метаболизма, что приводит к возрастанию устойчивости к повышенным температурам. Возрастание активности СОД возможно за счет экспрессии гетерологического цитохрома $\mathrm{P} 450_{\mathrm{ScC}}$, которая приводит к образованию супероксид радикалов. Полученные растения могут быть устойчивы к другим стрессовым воздействиям различного происхождения.

\section{РОСЛИНИ РІПАКУ 3 ТРАНСГЕНОМ cyp11A1 3А УМОВ КОРОТКОТРИВАЛОГО ВИСОКОТЕМПЕРАТУРНОГО СТРЕСУ}

\section{Л.О. Сахно, М.С. Сливець, М.В. Кучук}

Для вивчення стійкості трансгенних рослин ярого ріпаку (Brassica napus L.), які конститутивно експресують ген суp $11 \mathrm{~A} 1$, що кодує цитохром $\mathrm{P} 450_{\text {SCC }}$ великої рогатої худоби, до дії високих температур проаналізовано особливості росту за умов короткотривалого високотемпературного стресу $\left(42^{\circ} \mathrm{C}\right)$ в клімакамері. Результати цього тесту позитивно корелюють 3 підвищенням толерантності до дії високих температур в польових дослідах. На підставі збільшеного відносного вмісту води (на $13 \%$ ) і підвищеної активності СОД, а також зменшеного виходу електролітів (в 1,4 раза) і меншого підвищення вмісту хлорофілу $a$ і каротиноїдів в листках трансгенних рослин у порівнянні з рослинами дикого типу за умов стресу можна зробити висновок про підвищення термостійкості у рослин ріпаку 3 трансгеном сур11А1 порівняно з контролем. Збільшення активності СОД в наших трансгенних рослинах ріпаку, виявлене за нормальних умов, відіграє визначальну роль у біохімічних змінах рослинного метаболізму, що спричиняє зростання стійкості до підвищених температур. Зростання активності СОД можливо за рахунок активності цитохрому $\mathrm{P} 450_{\mathrm{scc}}$, в результаті якої відбувається утворення супероксид радикалів. Отримані рослини можуть бути стійкими до інших стресових впливів різного походження.

\section{REFERENCES}

1. Bhatnagar-Mathur P., Vadez, V., Sharma K.K. Transgenic approaches for abiotic stress tolerance in plants: retrospect and prospects // Plant Cell Rep. 2008. - 27, № 3. - P. 411-424.

2. Zang H.X., Hodson J.N., Williams J.P., Blumwald E. Engineering salt-tolerant Brassica plants : Characterization of yield and seed oil quality in transgenic plants with increased vacuolar sodium accumulation //
Proc. Nat. Acad. Sci. USA. - 2001. - 98, № 22. P. 12832-12836.

3. Gusta L.V., Benning N.T., Wu G. et al. Superoxide dismutase: an all-purpose gene for agri-biotechnology// Mol. Breed. - 2009. - 24, № 2. - P. 103-115.

4. Wang Y., Ying J., Kuzma M. et al. Molecular tailoring of farnesylation for plant drought tolerance and yield protection // Plant J. - 2005. - 43, № 3. P. 413-424.

5. Qi W., Zhang F., Sun F. et al. Over-expression of a conserved RNA-binding motif (RRM) domain ( $c s R$ RM2) improves components of Brassica napus yield by regulating cell size // Plant Breed. - 2012. - 131, № 5. - P. 614-619.

6. Lee S.-H., Ahsan N., Lee K.-W. et al. Simultaneous overexpression of both $\mathrm{CuZn}$ superoxide dismutase and ascorbate peroxidase in transgenic tall fescue plants confers increased tolerance to a wide range of abiotic stresses // J. Plant Physiol. - 2007. 164, № 12. - P. 1626-1638.

7. Sakhno L.O., Morgun B.V., Kvasko O.Y., Kuchuk M.V. Transformed canola plants expressing mammalian cyp $11 \mathrm{~A} 1$ gene of cytochrome $\mathrm{P} 450_{\mathrm{SCC}} / /$ Biotechnologia Acta. - 2010. - 3, № 5. - P. 74-82.

8. Sakhno L.O., Gocheva E.A., Komarnitskii I.K., Kuchuk N.V. Stable expression of the promoterless bar gene in transformed rapeseed plants // Cytology and Genetics. - 2008. - 42, № 1. - P. 16-22.

9. Spivak S.G., Berdichevets I.N., Litvinovskaya R.P. et $a l$. Some peculiarities of steroid metabolism in transgenic Nicotiana tabacum plants bearing the CYP11A1 cDNA of cytochrome $\mathrm{P} 450_{\mathrm{scC}}$ from the bovine adrenal cortex // Rus. J. Bioorg. Chem. - 2010. - 36, № 2. - P. 224-232.

10. Sakhno L.O., Ostapchuk A.M., Klochko V.V., Kuchuk $M . V$. Fatty acid oil composition of canola plants expressing mammalian cytochrome $\mathrm{P} 450_{\mathrm{SCC}}$ cyp $11 \mathrm{~A} 1$ gene// Advances in research and technology of rapeseed oil / Ed. E. Szłyk. - Torun, 2011. - P. 55-59.

11. Trehub M.S., Sakhno L.O. Transgenic Brassica napus plants expressing cytochrome $\mathrm{P} 450_{\mathrm{SCC}}$ cyp $11 \mathrm{~A} 1$ gene under in vitro osmotic stress conditions // Biotechnology and Plant Breeding. Perspective Towards Food Security and Sustainability : Int. Conf. - Radzikow, 2012. - P. 156.

12. Sakhno L.O. Seed germination features of canola plants expressing mammalian cytochrome $\mathrm{P}^{4} 50_{\mathrm{SCC}}$ cyp $11 \mathrm{Al}$ gene // Bull. Vavilov Society of Geneticists and Breeders of Ukraine. - 2011. - 9, № 2. - P. 253-259.

13. McKersie B.D., Bowley S.R., Harjanto E., Leprince $O$. Water-deficit tolerance and field performance of transgenic alfalfa overexpressing superoxide dismutase // Plant Physiol. - 1996. - 111, № 4. P. $1177-1181$.

14. Ben-Saad R., Ben-Ramdhan W., Zouari N. et al. 
Marker-free transgenic durum wheat cv. Karim expressing the AlSAP gene exhibits a high level of tolerance to salinity and dehydration stresses // Mol. Breed. - 2012. - 30, № 1. - P. 521-533.

15. He C., Zhang $W$., Gao Q. et al. Enhancement of drought resistance and biomass by increasing the amount of glycine betaine in wheat seedlings // Euphytica. - 2011. - 177, № 2. - P. 151-167.

16. Chen Z., Pan Y.H., An L.Y. et al. Heterologous expression of a halophilic archaeon manganese superoxide dismutase enhances salt tolerance in transgenic rice // Rus. J. Plant Physiol. - 2013. - 60, № 3. P. 359-366.

17. Havaux M., Tardy F. Loss of chlorophyll with limited reduction of photosynthesis as an adaptive response of Syrian barley landraces to high-light and heat stress // Aust. J. Plant Physiol. - 1999. - 26, № 6. - P. 569-578.

18. Hajirezaei M.-R., Peisker M., Tschiersch H. et al. Small changes in the activity of chloroplastic $\mathrm{NADP}^{+}$-dependent ferredoxin oxidoreductase lead to impaired plant growth and restrict photosynthetic activity of transgenic tobacco plants // Plant J. 2002. - 29, № 3. - P. 281-293.

19. Smolikova G.N., Laman N.A., Boriskevich O.V. Role of chlorophylls and carotenoids in seed tolerance to abiotic stressors // Rus. J. Plant Physiol. - 2011. 58, № 6. - P. 965-973.

20. Snider J.L., Oosterhuis D. M., Kawakami E. M. Genotypic differences in thermotolerance are dependent upon prestress capacity for antioxidant protection of the photosynthetic apparatus in Gossypium hirsutum // Physiol. Plant. - 2010. - 138, № 3. P. 268-277.

21. Jin S.H., Li X.Q., Jia X.I. Genotypic differences in the responses of gas exchange, chlorophyll fluorescence, and antioxidant enzymes to aluminium stress in Festuca arundinacea // Rus. J. Plant Physiol. 2011. - 58, № 4. - P. 560-566.

22. Beyer W.F., Fridovich I. Assaying for superoxide dismutase activity some large consequences of minor changes in conditions// Anal. Biochem. - 1987. 161, № 2. - P. 559-566.

23. Bradford M.M. A rapid and sensitive method for the quantitation of microgram quantities of protein utilizing the principle of protein-dye binding // Anal. Biochem. - 1976. - 72, № 2. - P. 248-254.
24. Blum A., Ebercon A. Cell membrane stability as a measure of drought and heat tolerance in wheat // Crop Sci. - 1981. - 21, № 1. - P. 43-47.

25. Wellburn A.R. The spectral determination of chlorophylls $a$ and $b$, as well as total carotenoids, using various solvents with spectrophotometers of different resolution // J. Plant Physiol. - 1994. - 144, № 3. P. 307-313.

26. Wahid A., Gelani S., Ashraf M., Foolad M.R. Heat tolerance in plants: an overview// Environ. Exp. Bot. - 2007. - 61, № 3. - P. 199-233.

27. Sakhno L.O., Slyvets M.S. Superoxide dismutase activity in transgenic canola // Cytology and Genetics. 2014. - 48, № 3. - P. 145-149.

28. Chung B.C., Matteson K.J., Voutilainen R. et al. Human cholesterol side-chain cleavage enzyme, P450scc: cDNA cloning, assignment of the gene to chromosome 15, and expression in the placenta // Proc. Nat. Acad. Sci. USA. - 1986. - 83, № 23. P. 8962-8966.

29. Yang X., Wen X., Gong H. et al. Genetic engineering of the biosynthesis of glycinebetaine enhances thermotolerance of photosystem II in tobacco plants // Planta. - 2007. - 225, № 3. - P. 719-733.

30. Jiang $Y$., Huang $B$. Drought and heat stress injury to two cool-season turfgrasses in relation to antioxidant metabolism and lipid peroxidation // Crop Sci. 2001. - 41, № 2. - P. 436-442.

31. Prichodko N.V. Change in permeability of cell membranes as a common link of mechanisms of nonspecific reaction of plants to environmental effects // Physiol. Biochem. Cult. Plants. - 1977. - 9, № 3. P. 301-309.

32. Basu P.S., Ali M., Chaturvedi S.K. Terminal heat stress adversely affects chickpea productivity in northern India - strategies to improve thermotolerance in the crop under climate change// ISPRS Archives XXXVIII-8/W3 Workshop Proceedings : Impact of Climate Change on Agriculture. - 2009. P. 189-193.

33. Wang F.-Z., Wang Q.-B., Kwon S.-Y. et al. Enhanced drought tolerance of transgenic rice plants expressing a pea manganese superoxide dismutase// J. Plant Physiol. - 2005. - 162, № 4. - P. 465-472.

Received 10.07.13 